\title{
PENGEMBANGAN SISTEM PENDUKUNG KEPUTUSAN UNTUK SELEKSI PENERIMAAN BEASISWA DENGAN METODE SAW DAN TOPSIS : STUDI KASUS UNIVERSITAS MUHAMMADIYAH TANGERANG
}

\author{
ACHMAD FAIZ ${ }^{1}$, NURCHOLIS ALI SYA'BANA ${ }^{2}$, MUHAMMAD HAFIZ ${ }^{3}$ \\ 1,2,3 Program Studi Magister Ilmu Komputer, Program Pascasarjana, Universitas Budi Luhur \\ Jl. Raya Ciledug, Petukangan Utara, Kebayoran Lama, Jakarta Selatan 12260 \\ Telp. (021) 5853753, Fax. (021) 5869225 \\ E-mail :achmadfaiz8@gmail.com, Nurcholisali1@gmail.com, Muhammad.hafiz862@gmail.com
}

\begin{abstract}
Abstrak
Pemberian beasiswa merupakan program kerja yang ada di setiap universitas. Dengan tujuan untuk meringankan biaya bagi mahasiswa yang kurang mampu. Masalah yang dihadapi saat seleksi adalah membutuhkan waktu yang lama dalam merekap data calon penerima dan sulit memberikan hasil yang sesuai sehingga kurang tepat sasaran dalam menentukan pemberian beasiswa. Tujuannya bagaimana mengembangkan rancangan sistem pendukung keputusan agar tepat sasaran dan bisa membantu pengambil keputusan agar lebih cepat dalam menentukan penerima beasiswa. Salah satu cara yang dapat digunakan dalam proses seleksi dengan menggunakan metode Saw dan Topsis. Karena konsep yang sederhana, mudah dipahami, komputasinya efisien dan memiliki kemampuan untuk mengukur kinerja relatif dari setiap alternatif keputusan dalam bentuk matematis sederhana. Adapun kriteria yang digunakan adalah IPK, Pendapatan orang tua, Tanggungan orang tua, keikutsertaan organisasi dan semester. Hasil dari penelitian dengan menggabungkan metode Saw dan Topsis berhasil dibangun sehingga hasil yang diberikan lebih tepat sasaran dan dapat mempercepat waktu dalam menyeleksi data pemberian beasiswa.
\end{abstract}

Kata kunci : Beasiswa, Sistem Pendukung Keputusan, Kriteria, SAW, TOPSIS

\section{Abstract}

Scholarships are a work program in every university. With the aim of reducing costs for underprivileged students. The problem faced during the selection process is that it takes a long time to recapitulate prospective recipient data and it is difficult to provide appropriate results so that it is not well targeted in determining the awarding of scholarships. The goal is to develop a decision support system design so that it is right on target and can help decision makers more quickly determine the recipients of scholarships. One method that can be used in the selection process is by using the Saw and Topsis methods. Because the concept is simple, easy to understand, its computation is efficient and has the ability to measure the relative performance of each decision alternative in a simple mathematical form. The criteria used are the GPA, income of parents, dependents of parents, participation in organizations and semesters. The results of the research by combining the Saw and Topsis methods have been successfully built so that the results given are more targeted and can speed up the time in selecting scholarship data.

Keywords: Scholarship, Decision Support System, Criteria, SAW, TOPSIS

\section{PENDAHULUAN}

Pemberian beasiswa merupakan program kerja yang ada di setiap universitas untuk meringankan biaya mahasiswa dalam menempuh masa studinya. Pemberian beasiswa dilakukan secara selektif sesuai aturan yang telah ditentukan. 
Universitas Muhammadiyah Tangerang menyediakan program beasiswa dalam satu tahun dua kali pada semester ganjil dan genap, Biro Administrasi dan Akademik Kemahasiswaan (BAAK) sebagai panitia menyalurkan beasiswa yang layak mendapatkan. Masalah yang dihadapi saat seleksi yang dilakukan yaitu membutuhkan waktu yang lama dalam merekap data karena harus dilakukan satu-persatu

sehingga proses berjalan lambat, padahal banyak data calon penerima beasiswa yang mendaftarkan diri. Kondisi ini menyebabkan kurang tepat sasaran dalam menentukan yang berhak mendapatkan.

Solusi dari masalah yang dihadapi adalah mengembangkan suatu sistem pendukung keputusan dengan menerapkan suatu metode perangkingan yang dapat mempermudah menentukan pemberian beasiswa agar tepat sasaran yaitu dengan menggunakan metode Saw melakukan pembobotan kriteria dan menormalisasikan matriks $\mathrm{R}$ dan metode Topsis melakukan perangkingannya dari nilai bobot yang didapat pada Saw. Karena konsep yang sederhana, mudah dipahami, komputasinya efisien dan memiliki kemampuan untuk mengukur kinerja relatif dari alternatif-alternatif keputusan dalam bentuk matematis yang sederhana. Dengan metode ini sehingga mendapatkan hasil yang lebih tepat sasaran dan dapat mempercepat waktu dalam menyeleksi data pemberian beasiswa.

\section{TINJAUAN PUSTAKA}

\section{Sistem Pendukung Keputusan}

Sistem pendukung keputusan atau Dicision Support System (DSS) adalah sebuah sistem yang mampu memberikan kemampuan pemecahan masalah maupun kemampuan pengkomunikasian untuk masalah dengan kondisi semi terstruktur dan tak terstruktur. Sistem ini digunakan untuk membantu pengambilan keputusan dalam situasi semi terstruktur dan situasi tidak terstruktur, dimana tak seorangpun tahu secara pasti bagaiamana keputusan seharusnya dibuat[1].

\section{Simple Additive Weighting (SAW)}

Metode yang sering dikenal dengan istrilah penjumlahan terbobot. Konsep dasar dari metode SAW adalah mencari penjumlahan terbobot dar rating kinerja pada setip alternatif pada semua atribut. Metode SAW membutuhkan proses normalisasi matriks keputusan (X) ke suatu skala yang dapat diperbandingkan dengan semua rating alternatif yang ada.

$$
r_{i j}=\left\{\begin{array}{l}
\frac{x_{i j}}{\operatorname{Max}_{i} x_{i j}} \\
\frac{\operatorname{Min}_{i j} x_{i j}}{x_{i j}}
\end{array}\right.
$$

Jika $j$ adalah atribut keuntungan (benefit)

Jika $\mathrm{j}$ adalah atribut biaya (cost)

Keterangan:

$\mathrm{Rij}=$ nilai rating kinerja normalisasi

$\mathrm{X} \mathrm{ij}=$ nilai atribut yang dimiliki dariu setiap kriteria

Max $x i j=$ nilai terkecil dari setiap kriteria

Benefit $=$ nilai terbesar adalah terbaik

Cost $=$ nilai terkecil adalah terbaik

\section{Technique for Order Preference by Similarity to Ideal Solution (TOPSIS)}

Metode Topsis adalah kategori Multi Criteria Decision Making (MCDM) yaitu Teknik pengambilan keputusan dari beberapa pilihan alternatif yang ada. Bertujuan untuk menentukan solusi ideal positif dan solusi ideal negatif. Kriteria manfaat merupakan kriteria dimana ketika nilai tersebut semakin besar makan semakin layak untuk dipilih. Sedangkan kriteria biaya merupakan kebalikan dari kriteria manfaat, apabila semakin kecil nilai tersebut mkan akan semakin layak untuk dipilih.

TOPSIS memerlukan rating kinerja setiap alternatif $\mathrm{Ai}$ pada setiap kriteria $\mathrm{Cj}$ yang ternormalisasi yaitu:

$$
r_{i j}=\frac{x_{i j}}{\sqrt{\sum_{\mathrm{i}=1}^{m} x_{i j}^{2}}}
$$


$\mathrm{i}=1,2, \ldots, \mathrm{m} ;$ dan $\mathrm{j}=1,2, \ldots . \mathrm{n}$.

Solusi ideal positif A+ dan solusi ideal negatif A- dapat ditentukan berdasarkan rating bobot ternormalisasi (yij) sebagai: $=$

$$
\begin{gathered}
y_{i j}=w_{i} r_{i j} \\
A^{+}=\left(y_{1}^{+}, y_{2}^{+}, \ldots, y_{n}^{+}\right) \\
A^{-}=\left(y_{1}^{-}, y_{2}^{-}, \ldots, y_{n}^{-}\right)
\end{gathered}
$$

Dengan $\mathrm{i}=1,2, \ldots, \mathrm{m}$; dan $\mathrm{j}=1,2, \ldots \mathrm{n}$.

Dengan

$y_{1}^{+}$

$=\left\{\begin{array}{c}\max y_{i j}: \text { Jika } j \text { adalah atribut keuntungan } \\ \min y_{i j}: \text { Jika } j \text { adalah atribut biaya }\end{array}\right.$

$y_{1}^{-}$

$=\left\{\begin{array}{c}\max y_{i j}: \text { Jika } j \text { adalah atribut biaya } \\ \min y_{i j}: \text { Jika } j \text { adalah atribut keuntungan }\end{array}\right.$

Jarak antara alternatif Ai dengan solusi ideal positif dan negatif dirumuskan dengan:

$$
D_{i}^{+}=\sqrt{\sum_{j=1}^{n}\left(y_{1}^{+}-y_{i j}\right)^{2}} ;
$$

Dimana

$D_{\mathrm{i}}^{+}=$Jarak alternatif ke-i dengan solusi ideal positif.

$y_{i}^{+}=$Elemen solusi ideal positif [i].

$y_{i j}=$ Elemen matriks ternormalisasi terbobot [i][j].

Jarak antara alternatif ke-i dengan solusi ideal negatif dirumuskan sebagai berikut :

$$
D_{i}^{-}=\sqrt{\sum_{j=1}^{n}\left(y_{i j}-y_{1}^{-}\right)^{2}} ;
$$

$D_{\mathrm{i}}^{-}=$Jarak alternatif ke-i dengan solusi ideal negatif.

$y_{i}^{-}=$Elemen solusi ideal negatif [i].

$y_{i j}=$ Elemen matriks ternormalisasi terbobot [i][j].
Menentukan Nilai Preferensi untuk setiap alternatif dirumuskan dengan:

$$
V_{i}=\frac{D_{i}^{-}}{D_{i}^{-}+D_{i}^{+}}
$$

Dimana

$V_{i}=$ Kedekatan tiap alternatif terhadap solusi ideal.

$D_{i}^{+}=$Jarak alternatif ke-i dengan solusi ideal positif.

$D_{i}^{-}=$Jarak alternatif ke-i dengan solusi ideal negatif.

Nilai $V_{i}$ yang lebih besar menunjukan bahwa alternatif ke-i lebih dipilih.

Dalam metode TOPSIS, alternatif yang optimal adalah yang paling dekat dengan solusi ideal positif dan paling jauh dari solusi ideal negatif.

\section{Kerangka Konsep}

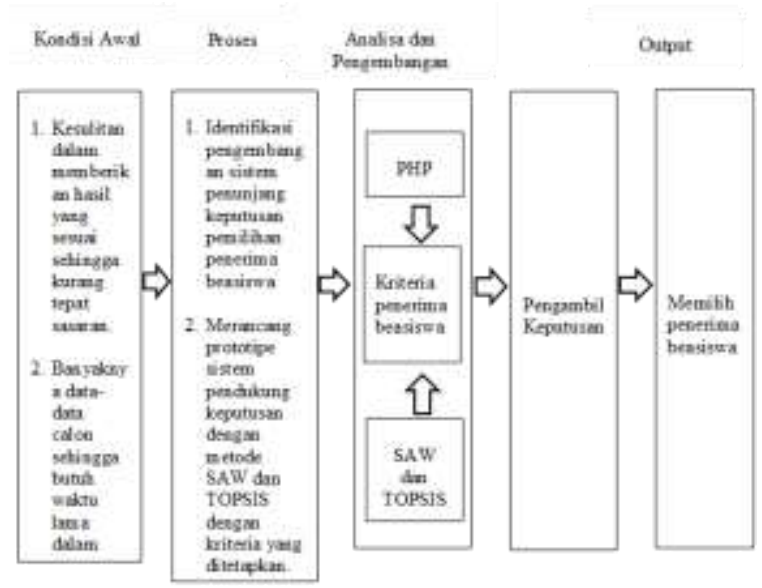

Gambar 1. Kerangka Konsep

Kondisi Awal atau Masalah

Panitia kesulitan dalam memberikan hasil yang sesuai sehingga kurang tepat sasaran dan banyaknya data calon penerima beasiswa yang masuk sehingga butuh waktu yang lama dalam menentukan beasiswa dengan kriteria yang ditentukan.

Proses

Setelah diketahui masalah yang ada kemudian merancang sebuah sistem penentuan penerima beasiswa dengan mengumpulkan informasi yang dikumpulkan. 
Analisa dan Pengembangan

Sistem dibangun menggunakan PHP dan menganalisa perhitungan dilakukan dengan menggunakan penggabungan metode Saw dan Topsis.

Diharapkan mampu memberikan hasil yang sesuai dan sistem dapat membantu pengambil keputusan dalam memberikan beasiswa lebih efisien dengan kriteria yang sudah ada.

\section{METODOLOGI PENELITIAN}

Tabel 1: Tabel Kriteria Benefit dan Cost

Kod

\begin{tabular}{|c|c|c|c|}
\hline e & Kriteria & Tipe & Keterangan \\
\hline $\mathrm{C} 1$ & Nilai IPK & $\begin{array}{l}\text { Benefi } \\
\mathrm{t}(+)\end{array}$ & $\begin{array}{l}\text { Semakin } \\
\text { tinggi nilainya } \\
\text { maka semakin } \\
\text { berpeluang }\end{array}$ \\
\hline $\mathrm{C} 2$ & $\begin{array}{l}\text { Pendapatan } \\
\text { Orang Tua }\end{array}$ & $\begin{array}{l}\text { Cost (- } \\
\text { ) }\end{array}$ & $\begin{array}{l}\text { Semakin } \\
\text { rendah } \\
\text { nilainya maka } \\
\text { semakin } \\
\text { berpeluang }\end{array}$ \\
\hline C3 & $\begin{array}{l}\text { Jumlah } \\
\text { Tanggungan } \\
\text { Orang Tua }\end{array}$ & $\begin{array}{l}\text { Benefi } \\
\mathrm{t}(+)\end{array}$ & $\begin{array}{l}\text { Semakin } \\
\text { tinggi nilainya } \\
\text { maka semakin } \\
\text { berpeluang }\end{array}$ \\
\hline $\mathrm{C} 4$ & $\begin{array}{l}\text { Keikutsertaa } \\
\text { n Organisasi } \\
\text { Mahasiswa }\end{array}$ & $\begin{array}{l}\text { Benefi } \\
\mathrm{t}(+)\end{array}$ & $\begin{array}{l}\text { Semakin } \\
\text { tinggi nilainya } \\
\text { maka semakin } \\
\text { berpeluang }\end{array}$ \\
\hline $\mathrm{C} 5$ & Semester & $\begin{array}{l}\text { Benefi } \\
\mathrm{t}(+)\end{array}$ & $\begin{array}{l}\text { Semakin } \\
\text { tinggi nilainya } \\
\text { maka semakin } \\
\text { berpeluang }\end{array}$ \\
\hline
\end{tabular}

Berikut adalah kriteria-kriteria dan nilai pada setiap atribut berdasarkan pengambil keputusan penerima beasiswa. Adapun bilangan dinilai dengan 1 sampai 5 dan kriterianya sebagai berikut :

$$
\begin{aligned}
& \text { Keterangan } \\
& \text { SR = Sangat Rendah } \\
& \mathrm{R}=\text { Rendah } \\
& \mathrm{C}=\text { Cukup } \\
& \mathrm{T}=\text { Tinggi } \\
& \text { ST }=\text { Sangat Tinggi }
\end{aligned}
$$

Gambar 2: Keterangan

Tabel 2. Skor Nilai Kriteria

\begin{tabular}{|c|c|}
\hline Skor & Keterangan \\
\hline
\end{tabular}

Sangat Rendah

2

Rendah

3

Cukup

4

Tinggi

5

Sangat Tinggi

Tabel 3. Nilai Indeks Prestasi Kumulatif

\begin{tabular}{cc}
\hline Nilai IPK & Nilai \\
\hline IPK $\leq 2,74$ & 1 \\
$2,75<$ IPK $\leq 2,99$ & 2 \\
$3,00<\operatorname{IPK} \leq 3,24$ & 3 \\
$3,25<$ IPK $\leq 3,74$ & 4 \\
$3,75<$ IPK $\leq 4,00$ & 5
\end{tabular}


Tabel 4. Penghasilan Orang Tua

\begin{tabular}{cc}
\hline $\begin{array}{c}\text { Penghasilan Orang Tua (tiap } \\
\text { bulan) }\end{array}$ & Nilai \\
\hline$X \leq 1,499,000$ & 5 \\
$1,500,000 \geq 2,999,000$ & 4 \\
$3,000,000 \geq 3,999,000$ & 3 \\
$4,000,000 \geq 4,499,000$ & 2 \\
$4,500,000 \geq$ & 1
\end{tabular}

Tabel 5. Tabel Tanggungan Orang Tua

\begin{tabular}{cc}
\hline Tanggungan Orang Tua & Nilai \\
\hline 1 anak & 1 \\
2 anak & 2 \\
3 anak & 3 \\
4 anak & 4 \\
$\geq 5$ anak & 5
\end{tabular}

Tabel 6. Keikutsertaan Organisasi

\begin{tabular}{cc}
\hline Keikutsertaan Angota & Nilai \\
\hline Pasif & 1 \\
Tingkat Jurusan & 2 \\
Tingkat Fakultas & 3 \\
Tingkat Universitas & 4 \\
Tingkat Antar Universitas & 5
\end{tabular}

Tabel 7. Semester

\begin{tabular}{cc}
\hline Semester & Nilai \\
\hline 3 & 1 \\
4 & 2 \\
5 & 3 \\
6 & 4 \\
7 & 5
\end{tabular}

Dari keriteria-kriteria diatas pengambil keputusan memberikn nilai bobot pada setiap kriteria penerima beasiswa sebagai berikut :

Tabel 8. Bobot pada setiap kriteria

\begin{tabular}{ccc} 
Kode & Kriteria & $\begin{array}{c}\text { Nilai } \\
\text { Bobot }\end{array}$ \\
\hline C1 & Nilai IPK & $30 \%$ \\
C2 & Pendapatan Orang Tua & $25 \%$ \\
C3 & Tanggungan Orang Tua & $20 \%$ \\
C4 & $\begin{array}{c}\text { Keikutsertan Organisasi } \\
\text { Mahasiswa }\end{array}$ \\
C5 & Semester & $15 \%$ \\
& $0,25 \quad 0,20$ & 0,15 \\
W & $0,10]$
\end{tabular}

Langkah-langkah penelitian pada penelitian ini dirumuskan pada Table di bawah ini: 


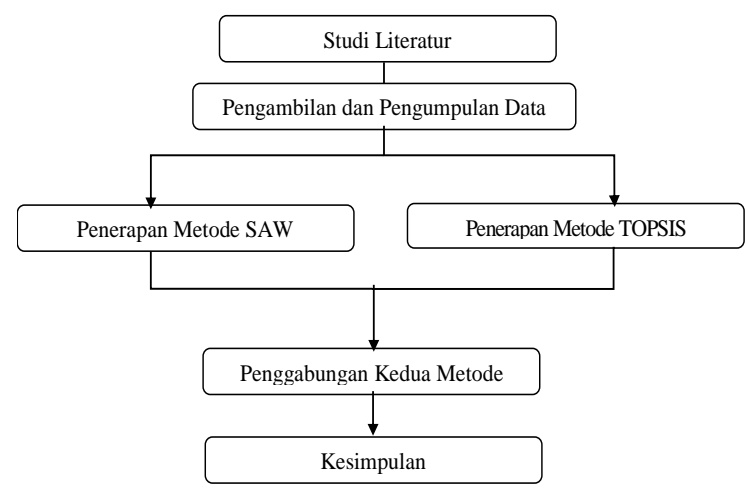

Gambar 3. Skema Langkah-langkah Penelitian

Adapun penjelasan dari skema langkahlangkah penelitian pada Gambar III.1 diatas sebagai berikut :

a. Studi Literatur

Langkah awal yang dilakukan adalam mengumpulkan berbagai literatur tentang metode SAW dan metode TOPSIS dari internet ataupun yang berhubungan dengan kedua metode tersebut.

b. Pengambilan dan Pengumpulan Data

Pada langkah ini, dilakukan pengambilan dan pengumpulan data tentang penentuan calon penerima beasiswa di Universitas Muhammadiyah Tangerang.

c. Penerapan Metode SAW dan Metode TOPSIS

Pada langkah ini menerapkan metode SAW dan TOPSIS tapi sebelumnya yaitu menentukan kriteria yang dibutuhkan untuk pengambilan keputusan berdasarkan persyaratan yang telah ditentukan. Adpaun kriteria yang telah ditentukan adalah Nilai Indeks Prestasi Kumulatif $\left(C_{1}\right)$, Pendapatann Orang Tua (tiap bulan) $\left(C_{2}\right)$, Jumlah Tanggungan Orang Tua $\left(C_{3}\right)$, Keikutsertaan Orang Tua $\left(C_{4}\right)$ dan Semester $\left(C_{5}\right)$

\section{HASIL DAN PEMBAHASAN}

Berikut adalah penjelasan langkah atau cara kerja metode Simple Additive Weighting (SAW) dan metode Technique for Order Preference by
Similarity of Solution (TOPSIS) secara manual, penyelesaiannya menggunakan data yang sama pada bab sebelumnya berupa 10 alternatif mahasisawa dan 5 atribut kriteria.

Tabel 9. Rating Kecocokan Alternatif pada Setiap Kriteria

\begin{tabular}{|c|c|c|c|c|c|}
\hline Alternatif & Nilai IPK & $\begin{array}{l}\text { Pendapatan } \\
\text { Orang Tua } \\
\text { (tiap bulan) }\end{array}$ & $\begin{array}{c}\text { Jumlah } \\
\text { Tanggungan } \\
\text { Orang Tua } \\
\end{array}$ & $\begin{array}{l}\text { Keikutsertaan } \\
\text { Organisasi }\end{array}$ & Semester \\
\hline FHIH 1574201003 & 5 & 4 & 4 & 4 & 5 \\
\hline FHIH 1674201138 & 5 & 5 & 3 & 5 & 3 \\
\hline FIKOM 1670201117 & 5 & 4 & 5 & 4 & 3 \\
\hline FIP 1565201067 & 5 & 5 & 4 & 4 & 5 \\
\hline FIP 1565201085 & 5 & 4 & 3 & 5 & 5 \\
\hline FIP 1665201077 & 5 & 4 & 4 & 5 & 3 \\
\hline FIP 1665201123 & 5 & 5 & 4 & 5 & 3 \\
\hline FTI 1555201549 & 5 & 4 & 5 & 5 & 5 \\
\hline FTM 1521201023 & 5 & 5 & 5 & 5 & 5 \\
\hline FTM 1721201104 & 5 & 5 & 5 & 5 & 1 \\
\hline \multicolumn{6}{|l|}{ Keterangan: } \\
\hline \multicolumn{6}{|c|}{$C_{1}=$ Nilai IPK } \\
\hline \multicolumn{6}{|c|}{$C_{2} \quad=$ Pendapatan Orang Tua } \\
\hline \multicolumn{6}{|l|}{$C_{3}$} \\
\hline \multicolumn{6}{|c|}{ anisas } \\
\hline \multicolumn{6}{|l|}{$C_{5}$} \\
\hline
\end{tabular}

Normalisasi Matriks Keputusan R.

Untuk Normalisasi nilai, Jika faktor kriteria benefit digunakan rumusan $\mathrm{Rii}=(\mathrm{Xij} / \max \{\mathrm{Xij}\})$ maka nilai-nilai normalisasi benefit menjadi :

$$
\begin{aligned}
& \mathrm{R}_{11}=\frac{5}{\operatorname{Max}\{5,5,5,5,5,4,5,4,4,5]}=\frac{5}{5}=1 \\
& \mathrm{R}_{21}=\frac{5}{\operatorname{Max}\{5,5,5,5,5,4,5,4,4,5]}=\frac{5}{5}=1 \\
& \mathrm{R}_{31}=\frac{5}{\operatorname{Max}\{5,5,5,5,5,4,5,4,4,5]}=\frac{5}{5}=1 \\
& \mathrm{R}_{41}=\frac{5}{\operatorname{Max}\{5,5,5,5,5,4,5,4,4,5]}=\frac{5}{5}=1 \\
& \mathrm{R}_{51}=\frac{5}{\operatorname{Max}\{5,5,5,5,5,4,5,4,4,5]}=\frac{5}{5}=1 \\
& \mathrm{R}_{61}=\frac{4}{\operatorname{Max}\{5,5,5,5,5,4,5,4,4,5]}=\frac{5}{5}=0,8 \\
& \mathrm{R}_{71}=\frac{5}{\operatorname{Max}\{5,5,5,5,5,4,5,4,4,5]}=\frac{5}{5}=1 \\
& \mathrm{R}_{81}=\frac{4}{\operatorname{Max}\{5,5,5,5,5,4,5,4,4,5]}=\frac{4}{5}=0,8 \\
& \mathrm{R}_{91}=\frac{4}{\operatorname{Max}\{5,5,5,5,5,4,5,4,4,5]}=\frac{4}{5}=0,8 \\
& \mathrm{R}_{101}=\frac{5}{\operatorname{Max}\{5,5,5,5,5,4,5,4,4,5]}=\frac{5}{5}=1
\end{aligned}
$$

Untuk Normalisasi nilai, Jika faktor kriteria cost digunakan rumusan $\mathrm{Rii}=(\min \{\mathrm{Xij}\} / \mathrm{Xij})$ maka nilai-nilai normalisasi cost menjadi : 
$\mathrm{R}_{12}=\frac{\operatorname{Min}\{4,5,4,5,4,4,5,4,5,5\}}{4}=\frac{4}{4}=1$
$\mathrm{R}_{22}=\frac{\operatorname{Min}\{4,5,4,5,4,4,5,4,5,5\}}{5}=\frac{4}{5}=0.8$
$\mathrm{R}_{32}=\frac{\operatorname{Min}\{4,5,4,5,4,4,5,4,5,5\}}{4}=\frac{4}{4}=1$
$\mathrm{R}_{42}=\frac{\operatorname{Min}\{4,5,4,5,4,4,5,4,5,5\}}{5}=\frac{4}{5}=0.8$
$\mathrm{R}_{52}=\frac{\operatorname{Min}\{4,5,4,5,4,4,5,4,5,5\}}{4}=\frac{4}{4}=1$
$\mathrm{R}_{62}=\frac{\operatorname{Min}\{4,5,4,5,4,4,5,4,5,5\}}{4}=\frac{4}{4}=1$
$\mathrm{R}_{72}=\frac{\operatorname{Min}\{4,5,4,5,4,4,5,4,5,5\}}{5}=\frac{4}{5}=0.8$
$\mathrm{R}_{82}=\frac{\operatorname{Min}\{4,5,4,5,4,4,5,4,5,5\}}{4}=\frac{4}{4}=1$
$\mathrm{R}_{92}=\frac{\operatorname{Min}\{4,5,4,5,4,4,5,4,5,5\}}{5}=\frac{4}{5}=0.8$
$\mathrm{R}_{102}=\frac{\operatorname{Min}\{4,5,4,5,4,4,5,4,5,5\}}{5}=\frac{4}{5}=0.8$

Jika disajikan dalam bentuk matriks berikut :

$$
R=\left[\begin{array}{ccccc}
1 & 1 & 0.8 & 0.8 & 1 \\
1 & 0.8 & 0.6 & 1 & 0.6 \\
1 & 1 & 1 & 0.8 & 0.6 \\
1 & 0.8 & 0.8 & 0.8 & 1 \\
1 & 1 & 0.6 & 1 & 1 \\
0.8 & 1 & 0.8 & 1 & 0.6 \\
1 & 0.8 & 0.8 & 1 & 0.6 \\
0.8 & 1 & 1 & 0.8 & 1 \\
0.8 & 0.8 & 1 & 0.8 & 1 \\
1 & 0.8 & 1 & 1 & 0.2
\end{array}\right]
$$

Setelah matriks ternormalisasi $\mathrm{R}$ diperoleh kemudian dilanjutkan dengan mencari nilai matriks terbobot $\mathrm{Y}$ dengan menggunakan metode topsis.

a. Normalisasi Matriks Terbobot Y berdasarkan nilai setiap elemen pada matriks ternormalisasi $\mathrm{R}$ yang diperoleh pada metode $\mathrm{SAW}$, dengan menggunakan persamaan (1.3):

$$
y_{i j}=W_{i} R_{i j}
$$

$\mathrm{Y}_{11=} 30 \times 1=30$

$\mathrm{Y}_{21}=30 \times 1=30$

$\mathrm{Y}_{31}=30 \times 1=30$

$\mathrm{Y}_{41}=30 \times 1=30$

$Y_{51}=30 \times 1=30$

$\mathrm{Y}_{61}=30 \times 0,8=24$

$\mathrm{Y}_{71}=30 \times 1=30$

$\mathrm{Y}_{81}=30 \times 0,8=24$

$\mathrm{Y}_{91}=30 \times 0,8=24$

$$
\begin{aligned}
& Y_{101}=30 \times 1=30 \\
& Y_{12}=25 \times 1=25 \\
& Y_{22}=25 \times 0,8=20 \\
& Y_{32}=25 \times 1=25 \\
& Y_{42}=25 \times 0,8=20 \\
& Y_{52}=25 \times 1=25 \\
& Y_{62}=25 \times 1=25 \\
& Y_{72}=25 \times 0,8=20 \\
& Y_{82}=25 \times 1=25 \\
& Y_{92}=25 \times 0.8=20 \\
& Y_{102}=25 \times 0,8=20
\end{aligned}
$$

$$
Y=\left[\begin{array}{ccccc}
30 & 25 & 16 & 12 & 10 \\
30 & 20 & 12 & 15 & 6 \\
30 & 25 & 20 & 12 & 6 \\
30 & 20 & 16 & 12 & 10 \\
30 & 25 & 12 & 15 & 10 \\
24 & 25 & 16 & 15 & 6 \\
30 & 20 & 16 & 15 & 6 \\
24 & 25 & 20 & 12 & 10 \\
24 & 20 & 20 & 12 & 10 \\
30 & 20 & 20 & 15 & 2
\end{array}\right]
$$

b. Menentukan Solusi Ideal Positif $\left(\mathrm{A}^{+}\right)$, dengan persamaan (1.4) :

$$
\begin{aligned}
& A^{+}=\left(y_{1}^{+}, y_{2}^{+}, y_{3}^{+}, y_{4}^{+}, y_{5}^{+}\right) \\
& y_{1}^{+}= \\
& \max (30,30,30,30,30,24,30,24,24,30)=30
\end{aligned}
$$$$
y_{2}^{+}=
$$

$\min (25,20,25,20,25,25,20,25,20,20)=20$

Dan seterusnya diperoleh :

$A^{+} \quad=(30,20,20,15,10)$

c. Menentukan Solusi ideal negatif $\left(\mathrm{A}^{-}\right)$, dengan persamaan (1.5):

$A-\quad=\left(y_{1}^{-}, y_{2}^{-}, y_{3}^{-}, y_{4}^{-}, y_{5}^{-}\right)$
$y_{1}^{-}=$
$\min (30,30,30,30,30,24,30,24,24,30)=24$
$y_{2}^{-}=$
$\max (25,20,25,20,25,25,20,25,20,20)=25$

Dan seterusnya diperoleh :

$A^{-} \quad=(24,25,12,12,2)$ 
d. Menentukan Jarak Terbobot setiap alternatif terhadap solusi ideal positif $\left(S_{1}^{+}\right)$, dengan persaman(1.6) :

$\left.D_{1}^{+}=\sqrt{\sum_{j-1}^{n}\left(y_{1}^{+}\right.}-y_{j}\right)^{2} ;$

$D_{1}^{+} \mathrm{A} 1=7.07107$

$D_{2}^{+} \mathrm{A} 2=8.94427$

$D_{3}^{+} \mathrm{A} 3=7.07107$

$D_{4}^{+} \mathrm{A} 4=5$

$D_{5}^{+} \mathrm{A} 5=9.43398$

$D_{6}^{+} \mathrm{A} 6=9.64365$

$D_{7}^{+} \mathrm{A} 7=5.65685$

$D_{8}^{+} \mathrm{A} 8=8.3666$

$D_{9}^{+} \mathrm{A} 9=6.7082$

$D_{10}^{+} \mathrm{A} 10=8$

e. Menentukan Jarak Terbobot setiap alternatif terhadap solusi ideal negatif $\left(S_{1}^{-}\right)$,ndengan persaman(1.7) :

$\left.D_{1}^{-}=\sqrt{\sum_{j-1}^{n}\left(y_{1}^{-}\right.}-y_{j}\right)^{2}$

$D_{1}^{-} \mathrm{A} 1=10.77033$

$D_{2}^{-} \mathrm{A} 2=9.27362$

$D_{3}^{-} \mathrm{A} 3=10.77033$

$D_{4}^{-} \mathrm{A} 4=11.87434$

$D_{5}^{-} \mathrm{A} 5=10.44031$

$D_{6}^{-} \mathrm{A} 6=6.40312$

$D_{7}^{-} \mathrm{A} 7=10.0995$

$D_{8}^{-} \mathrm{A} 8=11.31371$

$D_{9}^{-} \mathrm{A} 9=12.36932$

$D_{10}^{-} \mathrm{A} 10=11.57584$ f. Menentukan Nilai Preferensi untuk setiap alternatif, dengan persamaan (1.8) :

$V_{i}=\frac{D_{i}^{-}}{D_{i}^{-}+D_{i}^{+}}$

Maka diperoleh :

$$
\begin{array}{ll}
\mathrm{A} 1=\frac{7.07107}{7.07107+10.77033} & =0.60367 \\
\mathrm{~A} 2=\frac{8.94427}{8.94427+9.27362} & =0.50904 \\
\mathrm{~A} 3=\frac{7.07107}{7.07107+10.77033} & =0.60367 \\
\mathrm{~A} 4=\frac{5}{5+11.87434} & =0.70369 \\
\mathrm{~A} 5=\frac{9.43398}{9.43398+10.44031} & =0.52532 \\
\mathrm{~A} 6=\frac{9.64365}{9.64365+6.40312} & =0.39903 \\
\mathrm{~A} 7=\frac{5.65685}{5.65685+10.0995} & =0.64098 \\
\mathrm{~A} 8=\frac{8.3666}{8.3666+11.31371} & =0.57487 \\
\mathrm{~A} 9=\frac{6.7082}{6.7082+12.36932} & =0.70369 \\
\mathrm{~A} 10=\frac{8}{8+11.57584} & =0.59133
\end{array}
$$

Kemudian melakukan perangkingan calon penerima beasiswa berdasarkan Nilai $V_{i}$ yang didapat mulai dari yang terbesar yaitu alternatif : FIP 1565201067 - Suhaebah memiliki nilai tertinggi pertama dengan hasil $=0.704$.

\section{Perancangan Usecase}

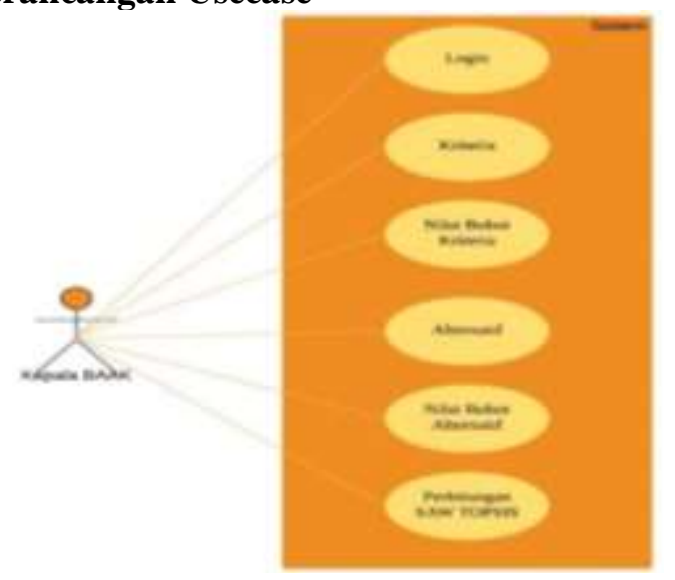

Gambar 4. Usecase Diagram Perangkingan 


\section{Activity Diagram}

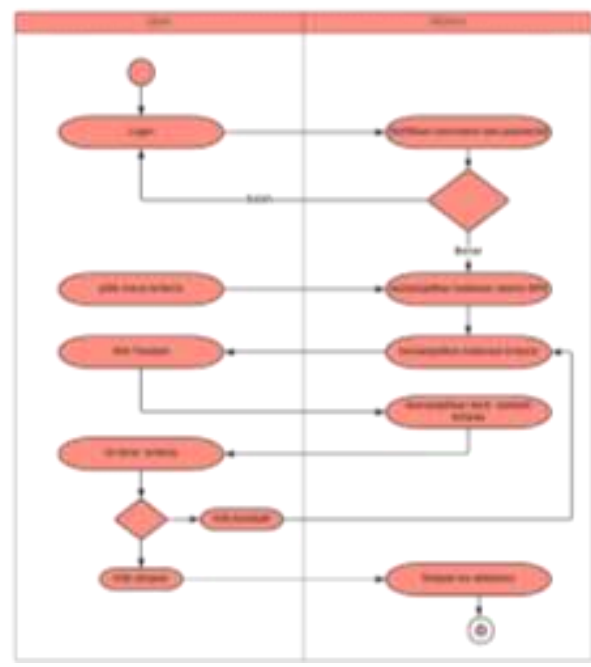

Gambar 5. Kriteria

\section{Hasil Implementasi}

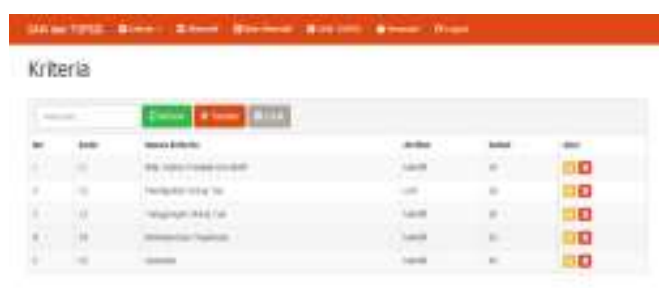

Gambar 6. Tampilan Menu Kriteria

\section{Pengujian UAT (User Acceptance Test)}

Pengujian UAT adalah suatu proses pengujian oleh user yang dimaksudkan untuk menghasilkan dokumen yang dijadikan bukti bahwa sistem yang dikembangkan dapat diterima atau tidaknya oleh user, apabila hasil pengujian sudah bisa dianggap memenuhi kebutuhan dari pengguna maka aplikasi dapat diterapkan. Pengujian dengan UAT dilakukan dengan mengajukan beberapa pertanyaan terhadap pimpinan, kepala BAAK dan staf pegawai yang bertindak sebagai pengguna, pengujian ini melibatkan 30 responden yaitu
Kepala BAAK, Panitia Beasiswa, Prodi dan Staf pegawai .

Hasil user acceptance test dinilai dengan 5 kategori diantaranya adalah : SS (Sangat Setuju), S (Setuju), RR (Ragu-ragu), TS ( Tidak Setuju), STS (Sangat Tidak Setuju). Berikut ini adalah rincian hasilnya.

Tabel 10. Pilihan dan Bobot Nilai Jawaban

\begin{tabular}{|llc|}
\hline $\begin{array}{c}\text { Alternatif } \\
\text { Jawaban }\end{array}$ & \multicolumn{1}{c}{ Keterangan } & Bobot \\
\hline SS $=$ & Sangat Setuju & 5 \\
$\mathrm{~S}=$ & Setuju & 4 \\
$\mathrm{R}=$ & Ragu-ragu & 3 \\
$\mathrm{TS}=$ & Tidak Setuju & 2 \\
STS $=$ & Sangat Tidak Setuju & 1 \\
\hline
\end{tabular}

Tabel 11. Pernyataan Pengujian UAT

\begin{tabular}{|c|l|c|c|c|c|c|}
\hline \multirow{2}{*}{ No. } & \multicolumn{1}{|c|}{ Pernyataan } & \multicolumn{4}{|c|}{ Alternatif Jawaban } \\
\cline { 3 - 7 } & & SS & S & R & TS & STS \\
\hline 1 & Apakah Prototipe ini mudah digunakan? & & & & & \\
\hline 2 & $\begin{array}{l}\text { Apakah prototipe ini dapat merespon } \\
\text { dengan cepat? }\end{array}$ & & & & & \\
\hline 3 & $\begin{array}{l}\text { Apakah tampilan prototipe ini layak } \\
\text { digunakan? }\end{array}$ & & & & & \\
\hline 4 & $\begin{array}{l}\text { Apakah prototipe ini sudah sesuai dengan } \\
\text { kebutuhan yang diharapakan? }\end{array}$ & & & & & \\
\hline 5 & $\begin{array}{l}\text { Apakah prototipe ini menghasilkan informasi } \\
\text { yang tepat? }\end{array}$ & & & & \\
\hline 6 & $\begin{array}{l}\text { Apakah secara keseluruhan anda setuju } \\
\text { dengan prototipe ini? }\end{array}$ & & & & \\
\hline
\end{tabular}

Tabel 12. Data Jawaban Pengujian UAT 


\begin{tabular}{|c|l|c|c|c|c|c|}
\hline \multirow{2}{*}{ No. } & \multicolumn{1}{|c|}{ Pernyataan } & \multicolumn{5}{|c|}{ Alternatif Jawaban } \\
\cline { 3 - 7 } & & SS & S & R & TS & STS \\
\hline 1 & Apakah Prototipe ini mudah digunakan? & 13 & 17 & & & \\
\hline 2 & $\begin{array}{l}\text { Apakah prototipe ini dapat merespon } \\
\text { dengan cepat? }\end{array}$ & 15 & 15 & & & \\
\hline 3 & $\begin{array}{l}\text { Apakah tamplan prototipe ini layak } \\
\text { digunakan? }\end{array}$ & 6 & 23 & 1 & & \\
\hline 4 & $\begin{array}{l}\text { Apakah prototipe ini sudah sesuai dengan } \\
\text { kebutuhan yang diharapakan? }\end{array}$ & 4 & 25 & 1 & & \\
\hline 5 & $\begin{array}{l}\text { Apakah prototipe ini menghasikan informasi } \\
\text { yang tepat ? }\end{array}$ & 11 & 17 & 1 & & \\
\hline 6 & $\begin{array}{l}\text { Apakah secara keseluruhan anda setuju } \\
\text { dengan prototipe ini? }\end{array}$ & 17 & 13 & & & \\
\hline
\end{tabular}

Data yang didapat di atas diolah dengan cara mengalikan setiap poin jawaban dengan bobot yang sudah ditentukan sesuai dengan tabel bobot yang sudah ditentukan sesuai dengan tabel bobot nilai jawaban. Dari hasil perhitungan dengan mengalikan setiap jawaban bobot yang sudah ditentukan maka didapat hasil sebagai berikut :

Tabel 13. Data Hasil Nilai Pengujian UAT

\begin{tabular}{|c|l|c|c|c|c|c|c|}
\hline \multirow{2}{*}{ No. } & \multicolumn{1}{|c|}{ Pernyataan } & \multicolumn{5}{|c|}{ Alternatif Jawaban } & Jml \\
\cline { 3 - 8 } & & SSx5 & Sx4 & Rx3 & TSx2 & STSx1 & \\
\hline 1 & $\begin{array}{l}\text { Apakah Prototipe ini mudah digunakan } \\
?\end{array}$ & 65 & 68 & 0 & 0 & 0 & 133 \\
\hline 2 & $\begin{array}{l}\text { Apakah prototipe ini dapat merespon } \\
\text { dengan cepat? }\end{array}$ & 75 & 60 & 0 & 0 & 0 & 135 \\
\hline 3 & $\begin{array}{l}\text { Apakah tamplan prototipe imi layak } \\
\text { digunakan? }\end{array}$ & 30 & 92 & 3 & 0 & 0 & 125 \\
\hline 4 & $\begin{array}{l}\text { Apakah prototipe ini sudah sesuai } \\
\text { dengan kebutuhan yang diharapakan? }\end{array}$ & 20 & 100 & 3 & 0 & 0 & 123 \\
\hline 5 & $\begin{array}{l}\text { Apakah prototipe ini menghasiikan } \\
\text { informasi yang tepat? }\end{array}$ & 55 & 68 & 3 & 0 & 0 & 126 \\
\hline 6 & $\begin{array}{l}\text { Apakah secara keseluruhan anda setuju } \\
\text { dengan prototipe ini? }\end{array}$ & 85 & 52 & 0 & 0 & 0 & 137 \\
\hline
\end{tabular}

a. Analisa pertanyaan pertama dari tabel diatas dapat dilihat bahwa hasil jumlah nilai dari 30 responden untuk pertanyaan pertama adalah 133 . Nilai rata-ratanya adalah $133: 30=4.4$. persentase nilainya adalah $4.4: 5 \times 100=88.6 \%$

b. Analisa pertanyaan kedua dari tabel diatas dapat dilihat bahwa hasil jumlah nilai dari 30 responden untuk pertanyaan kedua adalah 135 . Nilai rata-ratanya adalah $135: 30=4.5$. persentase nilainya adalah $4.5: 5 \times 100=90 \%$

c. Analisa pertanyaan ketiga dari tabel diatas dapat dilihat bahwa hasil jumlah nilai dari 30 responden untuk pertanyaan ketiga adalah 125 . Nilai rata-ratanya adalah $125: 30=4.2$. persentase nilainya adalah $4.2: 5 \times 100=83 \%$

d. Analisa pertanyaan keempat dari tabel diatas dapat dilihat bahwa hasil jumlah nilai dari 30 responden untuk pertanyaan keempat adalah
123. Nilai rata-ratanya adalah $123: 30=4.1$. persentase nilainya adalah $4.1: 5 \times 100=82 \%$

e. Analisa pertanyaan kelima dari tabel diatas dapat dilihat bahwa hasil jumlah nilai dari 30 responden untuk pertanyaan kelima adalah 126 . Nilai rata-ratanya adalah $126: 30=4.2$. persentase nilainya adalah $4.2: 5 \times 100=84 \%$

f. Analisa pertanyaan keenam dari tabel diatas dapat dilihat bahwa bahwa hasil jumlah nilai dari 30 responden untuk pertanyaan keenam adalah 137. Nilai rata-ratanya adalah $137: 30=4.6$. persentase nilainya adalah $4.6: 5 \times 100=91.3 \%$

Dari data diatas dapat disimpulkan bahwa pertanyaan keenam memiliki nilai terbesar dengan total $91.3 \%$ yaitu secara keseluruhan "anda setuju dengan prototipe ini".

\section{KESIMPULAN}

Berdasarkan dari uraian yang dijelaskan, maka kesimpulan yang didapat dari penelitian ini sebagai berikut:

- Pengembangan sistem pendukung keputusan untuk seleksi pemberian beasiswa dengan menggabungkan metode SAW dan TOPSIS telah berhasil dibangun sehingga hasil yang diberikan lebih tepat sasaran.

- Penggabungan metode SAW dan TOPSIS dapat mempercepat waktu dalam menyeleksi data pemberian beasiswa.

\section{SARAN}

Dari kesimpulan diatas, maka penelitian berikutnya disarankan untuk memperluas sampel penelitian dan dengan menggunakan penggabungan metode yang lainnya. 


\section{DAFTAR PUTAKA}

A.S Rosa, dan M.Shalahuddin. 2014. Rekayasa Perangkat Lunak Struktur dan Berorientasi Objek. Bandung: Informatika.

Hadi Cahyo Susandi, 2015, Aplikasi Metode SAW dan Metode TOPSIS untuk Penentuan Lokasi Tower BASE TRANSCEIVER STATION, Jurusan Matematika, Univeristas Jember, Jember.

Kusumadewi, S, Hartati, S, Harjoko, A \& Wardoyo, R, 2006, Fuzzy Multiple-Attribute Decision Making (FuzzyMADM) Yogyakarta.

R. A. Suherdi, R. Taufiq, A. A. Permana. "Penerapan Metode AHP dalam Sistem Pendukung Keputusan Kenaikan Pangkat Pegawai Di Badan Kepegawaian Dan Pengembagan Sumber Daya Manusia Kota Tangerang," in SINTAK, 2018, pp. 522-528 